\title{
Measuring Brand Image: Shopping Centre Case Studies
}

\author{
Author's version of the paper published in the: \\ International Review of Retail, Distribution and Consumer Research (2002) 12 (4): 353-373 \\ Charles Dennis, John Murphy, David Marsland, Tony Cockett and Tara Patel \\ Contact address: \\ * Brunel Business School, Brunel University \\ Uxbridge, Middlesex, UB8 $3 P H, U K$ \\ Phone: +44 (0) 1895265242 Fax: +44 (0) 1895203149 \\ Email: charles.dennis@brunel.ac.uk
}

Note: An earlier version of this paper was presented to the $11^{\text {th }}$ International EARCD Conference on Retail Innovation, ESADE, Barcelona, July 13-14, 2000.

Dr Charles Dennis is a Chartered Marketer and a lecturer in Marketing and Retail Management at Brunel University, London, UK. Originally a Chartered Chemical Engineer, his early career included some years in Engineering and Technical posts, latterly with a 'marketing' emphasis. Industrial experience was followed by seven years with 'Marketing Methods'; Institute of Marketing approved consultant, leading to training and then lecturing. He has been full-time in this current post since 1993.

Professor John Murphy is the founder and former chairman of Interbrand, responsible for some of the UK's best-known brand names. He has published widely on branding and trademarks, including the pioneering work on brand valuation. He is currently Chairman of St Peter's Brewery Company Ltd and is visiting Professor of Marketing at the Open University Business School.

Professor David Marsland (MA, PhD, FRSH) is a graduate of Cambridge University and LSE. Through the centre for Evaluation Research at Brunel University (London, UK), he is working on a programme of research on the modernisation of public and private sector organisations. His latest book 'Welfare or Welfare State?' was published by Macmillan in 1996. He is currently completing a textbook on research methods.

Dr Tony Cockett (BSc, MSc, MTech, PhD) is a Cybernetician and lecturer in Multimedia Design at Brunel University, London. Tony has a background in Cybernetics and has spent several years establishing the undergraduate subject of Multimedia Design at the University. He was for nearly 20 years Head of the University Department of Business. Tony has also spent nearly 15 years in industry where he worked as a designer.

Tara Patel (BSc) is a postgraduate research student at Brunel University. 


\title{
Measuring Brand Image: Shopping Centre Case Studies
}

Keywords: Shopping centres; Branding; Image; Attractiveness.

\begin{abstract}
'Branding' is well known for consumer products. Power has shifted from manufacturers' brands towards retailers'. Branding may become more important for shopping centres. The authors firstly investigated qualitatively. Shoppers described centres in 'personality' terms. One in-town centre was 'dull, boring and old-fashioned ... not exciting, just OK'. A larger regional centre was 'trendy, prestigious ... strong, vibrant, big and colourful'.
\end{abstract}

Secondly, the authors evaluated quantitatively. Their method was applied to six UK shopping centres, via a questionnaire survey of 287 shoppers. The 'strong and vibrant' centre scored significantly higher than the 'dull and boring' one. 'Pro-active marketing' is central to UK shopping centres. Despite 'branding' being little used, active brand management of shopping centres can pay rewards in customer numbers, sales turnover and rental income. 


\section{Measuring Brand Image: Shopping Centre Case Studies}

\section{Introduction and Conceptual Framework}

The concept of 'branding' is well known for consumer products. Successful manufacturers have built up brand value through the development of a differentiated brand personality and a long-term reputation for quality backed up by advertising and other forms of brand support. Concentration in retailing has led to the balance of marketing 'power' shifting from manufacturers towards retailers, whose brands have increased in prominence (McGoldrick, 1990). Jary and Wildman (1998) questioned whether retail businesses are really brands. They concluded that retail brands are 'The Real Thing' although differing from product brands 'not least because of the difficulty of managing the multiplicity of attributes of a retail brand'. The larger retailers are building their brands - for example the leading multiple grocer Tesco is in the top 10 (out of 115) major UK companies 'committed to building powerful brands' (Brand Finance, 1999). Retailers have become more aware of the value of branding and have (according to Davies, 1998) attempted to copy the images of manufacturers' brands in developing their own brands.

There is a strong link between retail concentration and the share of trade taken by retailer brands (Akehurst and Alexander, 1995). Just as consumers' preferences are moving towards fewer, larger retail stores, so they are also moving towards larger shopping centres. Between 1986 and 1999 the number of 'super-regional' shopping centres (over $100,000 \mathrm{~m}^{2}$ ) in the UK rose from two to seven (based on Guy, 1994). Shopping centres have been branded in practice - Arndale for example has been known as a leading shopping centre brand since the opening of the UK's first regional centre (at Poole) in 1969.

Brand names affect perception (evidenced by the well known example that over half of consumers chose Diet Pepsi in blind tests, but when they knew the brand names, almost two thirds preferred Diet Coke - de Chernatony and McDonald, 1998). As Jobber (2001, p. 229) puts it: 'a rose by any other name would smell as sweet' ... or would it?'. More 
than one of the shopping centres in our study was under the same ownership - but shoppers would probably not have known this. Many UK shopping centres do not make use of a name in branding to any extent. Exceptions include Arndale and also notably The Bentall Centre in Kingston on Thames, which benefits from association with a wellknown department store having a long history and a reputation for quality. For the future it might be expected that more shopping centres may follow the general retail trend and seek to build their brand images.

Others have studied the marketing of shopping destinations, including work by the Association of Town Centre Managers (e.g. 1994) and Warnaby and associates (e.g. Medway et al., 1999, 2000; Warnaby and Davies, 1997; Warnaby, 1998; Warnaby and Medway, 2000). In addition, there has been a considerable body of research into shopping centre choice based on Central Place Theory (founded on the work of Christaller, 1933) and Spatial Interaction (dating from Reilly, 1929 but developed by many others including Huff, 1964; McGoldrick and Thompson, 1992a, b; and Dennis, 2000a) which has identified and measured centre attributes to explore hierarchies and catchment areas. Nevertheless there has been little research to date, in the UK, on the branding of shopping centres. According to Howard (1992), shopping centres have largely ignored centre branding considerations. In this paper, the authors report a preliminary exploration of the potential for shopping centre branding using UK case studies. The aim is firstly to demonstrate that both qualitative and quantitative brand image measurement techniques can be of use for shopping centres and secondly to explore whether shopping centres might put brand-building techniques to use.

Planned shopping centres make up an important part of the UK economy and employment. Shopping centres employ over three-quarters of a million people and represent a substantial proportion of the investments of pension funds' (OXIRM, 1999; Davies et al., 1993). The success of shopping centres is important to ordinary people as employees, customers and pension holders. For the purposes of this paper, a shopping centre is defined as a centrally managed, planned retail provision having at least three shops (based on Guy, 1994). 
Why is the branding of shopping centres important? Aaker (1991) describes one approach to brand equity based on the use of share price data. When the costs of an organisation's tangible assets, together with non-brand values such as technology are subtracted from the total share price value, brand equity can be estimated. Shopping centres may well not aspire to the brand equity levels of the food or clothing industries (which Aaker states to be around $60 \%$ of asset values). Nevertheless, the potential financial value for investors can be glimpsed from an annual report of Capital Shopping Centres PLC (CSC, 1996, p. 8):

'The MetroCentre achieved a $17.5 \%$ increase in asset value [based on independent valuation] from $£ 354$ million to $£ 416$ million reflecting the value of CSC's active management expertise in its first year of ownership ..'

The substantial increase in asset valuation reflecting what CSC termed 'active management' arose mainly from a growth in rental values. A small but significant proportion of rents were sales-turnover-related, and in addition to this immediate effect on rents, rental values in the medium to long term tend to follow sales turnover. The increases in rental values were presumably linked to shoppers' and retailers' value of the 'attractiveness' of the MetroCentre. The example illustrates that there is a huge financial potential for less actively managed shopping centres to improve their attractiveness or 'brand image'.

Active management and pro-active marketing are features of the most successful shopping centres (CSC, 1996; Howard, 1997; Mintel, 1997). Even so, UK shopping centres have been reported to lack marketing orientation (Kirkup and Rafiq, 1999, drawing support from Cooke, 1993), which Howard (1995) blames on the industry's property investment focus.

The lack of marketing orientation goes hand-in-hand with a lack of branding. Shopping centres though face increasing competition. Even on conservative estimates, shopping centres are forecast to lose near to double figures percentage points of business to e-tailers in key sectors such as clothing, books and music (Gibson, 1999, Prefontayne, 1999, RICS Foundation, 2000). The authors contend that a more market-orientated approach is 
essential for UK shopping centres. Building brand values could pay off in terms of shopper satisfaction, rental levels and asset values.

According to Randall (1997), branding is fundamental to the success of many organisations. The authors believe that in the increasingly competitive climate branding will become even more relevant for shopping centres. This study, therefore, has set out to investigate the applicability of brand measurement techniques for shopping centres and to propose simple preliminary ideas for ways in which shopping centre managers might use standard brand-building tools.

What do we mean by 'brand'? Hankinson and Cowking (1993 p.1) defined the term as making a product or service distinctive by its 'personality' and 'positioning relative to the competition'. Personality 'consists of a unique combination of functional attributes and symbolic values' and positioning 'describes the brand by defining its competitive context' i.e. distinctiveness.

Personality. According to de Chernatony and McDonald (1998, p. 407), 'personality is a useful metaphor ... the brand is used to make a statement about the user'. De Chernatony and McDonald emphasised the importance of brand personality, particularly in cases where there are only minor variations in physical characteristics.

Distinctiveness. The need to distinguish from competitors is central to 'branding'. A number of authors have commented (directly or indirectly) on the distinctiveness of shopping centres (Burns and Warren, 1995; Howell and Rogers, 1980; SERPLAN, 1987). USA shopping centres have been reported as in decline (Carlson 1991) ascribed to a lack of distinctiveness (Cavanaugh, 1996; Wakefield and Baker, 1998). Swinyard (1992, p.9) measured 'distinctiveness' and concluded that the successful retailer must 'distinguish itself from its competitors in appealing ways.' Dennis and colleagues (1999) demonstrated that differences between shopping centres play an essential part in patronage decisions. 
Building successful brands. How can shopping centre brands be built? Jobber (1995; 2001, drawing support from King, 1991 and Doyle, 1989), lists factors that can be important in building successful brands: (1) Being first; (2) Quality; (3) Positioning; (4) Repositioning; (5) Long-term perspective; (6) Internal marketing; (7) Credibility and (8) Well-blended communications.

For this study we have used firstly Hankinson's and Cowking's then Jobber's approaches in designing the framework. Firstly, we have considered the use of brand personality techniques in eliciting customers' understandings of shopping centres. Secondly, we have investigated the distinctiveness of shopping centres relative to their competitors. Finally, we have outlined the possible implications in terms of building successful brands.

\section{Methodology and procedures}

In measuring brand personality, researchers such as Aaker (1997) and Alt and Griggs (1988) and have used psychometric approaches to demonstrate that brands can be described in terms similar to humans. Our approach has been to consider the 'personality' of a shopping centre using human type descriptors together with positioning relative to the competition in terms of the attributes or constructs making up a respondent's image of a shopping centre. Although the brand 'personality' of a shopping centre (if it has one) cannot be considered the same thing as its 'attractiveness', both aspects are part of the overall concept of branding. Indeed, looking for definitions of retail 'image', we find descriptors that fit both the concepts of symbolic or psychological values and measurements of perceptions of tangible, functional attributes (e.g. Martineau, 1958). 'Branding' spans the various concepts and terms such as the 'development and maintenance of sets of product attributes and values which are coherent, appropriate, distinctive, protectable and appealing to customers' (Murphy, 1998, p. 3). Rather than dividing the study along unclear semantic boundary lines of image and attractiveness, in this work we have reported our observations as categorised into qualitative, semiqualitative and quantitative work.

In the qualitative and semi-qualitative part of this study, we report summaries of the results of focus groups, personal constructs and semi-structured questionnaires. Here, we 
have followed de Chernatony's and McDonald's (1998, p. 407) approach in 'gauging the image associated with a brand' with questions like 'if [the shopping centre] came to life, what sort of person would it be?' On the other hand, in the quantified attribute approach, we have used Aaker's (1991) procedure of multiplying 'Importance' by 'Rating' and have combined this with Butterfield and Haigh's (1998) assignment of weights to brand image attributes. In the 'Interbrand' or 'Brand Finance' approaches the assignment of weights is 'judgmental' (Birkin, 1994; Murphy, 1989). In contrast, as an essential part of our procedure we have calculated attribute weights according to their degree of association with shopper spend. The Interbrand and Brand Finance methods are intended for brand valuation for accounting purposes rather than measuring image, but the principles serve well in our attributes-measurement approach.

The study was designed to explore the branding of exemplar shopping centres in three stages. The empirical work consisted of a series of linked investigations aimed at exploring the broad area of branding and attractiveness of shopping centres from different methodological perspectives. Firstly, qualitative and semi-qualitative techniques were used to compare 'personality' differences between two shopping centres. Secondly, the distinctiveness relative to the competition of six shopping centres was evaluated using quantitative techniques. Finally, the utility of shopping centre image measurements was examined, considering sales turnover, rental incomes and catchment area boundaries as dependent variables.

\section{Qualitative and semi-qualitative}

The first stage in the qualitative study took the form of six focus groups. The respondents were shoppers familiar with two shopping centres, the Metropolitan Centre and The Woodlands (these are not the real names as the centres have requested anonymity). These initial groups comprised six to eight respondents each, many of who (for convenience) were university students in the West London (UK) area. Students' views may not be representative of all UK shoppers. Therefore a final focus group was carried out with 10 respondents including both sexes with a range of ages and socio-economic classifications. The respondents of this final focus group were not previously known to the interviewer or to each other. 
A second stage comprised a 'Repertory Grid' to investigate shoppers' personal constructs in shopping at the two town centres that included the Metropolitan Centre and The Woodlands. The sample consisted of 20 participants, selected on a convenience basis from shoppers known to shop at the centres. As Oppewal and Timmermans (1999) pointed out, the technique avoids one of the drawbacks of attitude scales in that the respondents rather than the researcher can specify the items that shoppers like and dislike. The disadvantage is that the analysis process is lengthy and convoluted. In comparison with conventional in-depth interviews, the interpretation of the Repertory Grid (based on the work of Kelly, 1955; Fransella and Bannister, 1997) is more objective. Timmermans and associates (1982) used the technique to elicit the constructs which shoppers use in their choices of (Netherlands) shopping centres. A number of authors have used Repertory Grid in grocery shopping studies (for UK examples, see Hallsworth, 1988a; b; Mitchell and Kiral, 1999; Opacic and Potter, 1986). The repertory grid study will be reported more fully elsewhere but for a concise description of the techniques applied in a similar application, the reader is directed, for example, to Hallsworth (1988a).

The work with focus groups and Repertory Grid confirmed that shoppers were readily able to describe shopping centres in human personality terms. As a follow-up to the exploratory qualitative studies, a semi-structured questionnaire was carried out with a further 40 respondents. The respondents were selected on a convenience basis from shoppers known to shop at the centres. The semi-structured questionnaire was based on constructs derived from the focus groups and repertory grid and was designed to elicit 'personality' descriptions of the two centres.

\section{Quantitative}

The quantitative attribute measurement part of this study was based on empirical measurements of the attractiveness of shopping centres, together with shoppers' perceived travel distances and times, from shoppers' responses to structured questionnaires. Ideally, a random sampling technique would have been used but without a sampling frame this was not possible. Rather, the respondents were a convenience sample selected from shoppers in shopping centre malls at the times of the survey (weekdays, 10.30 a.m. to 3.30 
3.30 p.m.). Respondents were asked for their comparative ratings of two shopping centres, one of them the centre where the interview took place. The alternative centre evaluated by each respondent was the one where they shopped most (or next most after the centre where the respondent was interviewed) for non-food shopping. The questionnaire was based on the 'attributes of image' studied by McGoldrick and Thompson (1992a and b). These in turn had been sourced from the 'trade press' and included the topics derived from Repertory Grid study by Timmermans and associates (1982). Additional constructs were included from our own in-depth investigations. Respondents were asked for their perceptions of the 'importance' of each of 38 attributes (such as 'Quality of stores', 'Cleanliness' and 'Availability of toilets', following Hackett and Foxall, 1994). They also 'rated' each attribute for both the centre studied and the alternative centre. Respondents were asked to estimate perceived travel distance and time to both centres and to state details such as age, location of residence and occupation of the main earner in the household. Examination of the characteristics of the sample indicated the distribution of socio-economic groups, age and sex reasonably representative of that anticipated at UK shopping centres.

Respondents were asked to report their typical spend in an average month at each of the two centres. As McGoldrick and Thompson point out, much of the variation in shoppers' expenditure relates to factors such as income or socio-economic groups, rather than travel distance or image attributes of the shopping centre. Following this approach, the main dependent variable used in this study was the 'individual relative spend'. A value of 100 indicates all expenditure at the centre studied none at the alternative centre. A value of 50 indicates half of the expenditure at each centre.

The centres with their numbers of respondents were:

Blue Rose

White Water

Jubilee

Metropolitan

Greenleys

The Woodlands

Total
Large, out-of-town, regional $\quad 50$

In-town, regional 73

In-town, sub-regional $\quad 56$

In-town, sub-regional $\quad 51$

In-town, sub-regional 28

In-town, regional $\underline{29}$ 
In this terminology, a 'regional' shopping centre has a gross retail area of greater than $50000 \mathrm{~m}^{2}$ and a sub-regional one 20000 to $50000 \mathrm{~m}^{2}$ (based on Guy, 1994; Marjanen, 1993). Despite the small sample sizes of this exploratory study, it is interesting to compare the differences in the results between the centres.

The respondents' answers were processed to produce a satisfaction rating for each attribute variable. Firstly, the 'rating' values for the centre studied and the alternative centre were each coded on a 1 to 5 scale, where $1=$ very poor and $5=$ very good. This is the semantic differential approach proposed by Osgood et al., (1957), commonly accepted and used in marketing research. One of the benefits of the approach is that it is 'particularly good for brand comparisons' (Phipps and Simmons 1996, p. 103). The difference between these two ratings was used as a composite 'rating/distinctiveness' measure (each value was increased numerically by the addition of 4 to ensure that the measure was always positive). The 'importance' responses were also coded on a 5-point scale. The 'rating/distinctiveness' values were then multiplied by the 'importance' values. The 'expectancy' approach of multiplying rating by weighted importance may seem arbitrary as the function of the relationship (if any) could conceivably follow any form. Nevertheless, in the absence of contrary information, this is an accepted approach in marketing research, and is recommended by Aaker (1991) for comparing brands. The approach has a basis in theory as analogous to the Fishbein Compensating Model which measures an 'attitude' by multiplying 'strength of belief' about an attribute by the 'evaluation' of the attribute (Fishbein 1963).

A further step was to multiply the resulting values by a 'weight' representing the degree of association of each attribute with respondents relative spend at the centre studied, using a procedure similar to the 'Interbrand' or 'Brand Finance' approach. Unlike those methods, the assignment of weights was not 'judgemental'. Rather, the weight represented a combination measure obtained by multiplying the strength (regression coefficient) by the degree $\left(\mathrm{R}^{2}\right)$ of the association of the attribute with relative spend. The resulting values represented the respondents' satisfactions for each attribute. The satisfactions for all attributes were then added to give each respondent's total satisfaction score for the centre studied. The average of the respondents' satisfaction scores represented a measured 
represented a measured attractiveness for each centre. The scores were rescaled on a 0 to 100 scale, the 'Attractiveness index' for brand image values reported in the Results Quantitative section below. This scale was such that a hypothetical centre scoring across the board '0s' for rating/distinctiveness (the lowest possible score) would have had a measured 'Attractiveness index' value of 0 . On the other hand, a centre scoring across the board ' $8 \mathrm{~s}$ ' for rating/distinctiveness (the highest possible score) would have had a measured attractiveness value of 100 .

Mintel (1997) reported an attractiveness measurement scale for shopping centres and towns, based on counting shops, scoring multiples higher than others and certain specific named retailers higher still. This simple scale has been reported to correlate well with both an equivalent scale from Management Horizons (1995) and with empirical measurements from questionnaire surveys (Dennis et al., 2000b). Our 'Attractiveness index' represents actual measured values for respondents' assessments of the attractiveness of the centres. It would therefore be interesting to explore whether our measured values correspond with simple 'shop count' ratings such as the 'Mintel' score.

There is a complicating factor, though. Intuitively, it could be considered that in the case of some in-town shopping centres, shoppers' evaluations of centre attractiveness might be influenced by the attractiveness also of surrounding shops. For example, there are anecdotal reports that the attractiveness of shopping at the Bentall Centre, Kingston-onThames, UK, is considerably increased by being close to the John Lewis department store - an upmarket store that is located outside the covered, managed area of the Bentall Centre. Our survey interviewers reported that respondents at the in-town centres made decisions to shop in the shopping centre and the town - not just the shopping centre alone. Therefore the 'Mintel scores' for in-town shopping centres needed to be modified to include a correction for the town stores outside the shopping centre. The applicable correction turns out to be that the shops outside the shopping centre should count $50 \%$ of their Mintel score, those inside the shopping centre, $100 \%$. The 50\% value is not purely nominal but rather, results in the best fit with the measured 'Attractiveness index' of the centre: $\mathrm{R}^{2}=0.92$. This $50 \%$ value gives a better fit than $48 \%\left(\mathrm{R}^{2}=0.90\right)$ or $52 \%\left(\mathrm{R}^{2}=\right.$ $0.89)$. 
On the basis of these results, in order to examine any relationship between measured attractiveness and, for example, shopping centre sales or rental values, we have amended our 'Attractiveness index' scores. This amendment took the form of a subtraction of the attractiveness of the out-of-centre shops. The correction was based on the Mintel shops count system, counting the out-of-centre shops at $50 \%$ of the in-centre ones. To facilitate these calculations, our attractiveness index has been rescaled arithmetically so as to use a scale numerically equivalent to the Mintel score. The conversion was achieved by utilising the linear regression model of 'Attractiveness index' vs. Mintel score to apply an arithmetic constant and a multiplication factor to the 'Attractiveness index' values. The resulting corrected scores are reported as the 'Brunel index' for brand image in the Results - Quantitative section below.

\section{Results}

\section{Qualitative and semi-qualitative}

The constructs that emerged from the focus groups are summarised in Appendix 1. These indicate consistent themes. The descriptions from the final (more representative) group included that if the Metropolitan Centre were an animal, it would be a 'cat or a dog - not exciting, just OK'. On the other hand, The Woodlands would be a 'tiger, lion or peacock: strong, vibrant, big and colourful'. If the Metropolitan Centre were a person, it would be 'dull, boring and old-fashioned - lower working class or elderly'. The Woodlands would be a 'trendy, prestigious, very smart person of good taste who enjoyed leisure'. The ten focus group respondents from the final group considered the Metropolitan Centre to be inferior to The Woodlands across a wide range of attributes, including choice of shops, eating places, crèche facilities and attractiveness in general.

The results of the Repertory Grid demonstrated many similarities between the two centres on shoppers' likes and dislikes. The main differences were in constructs that could be classified as 'Environment' and 'Socialising' for both of which the town centre which includes The Woodlands was more favourable than that of the Metropolitan Centre. It is interesting to note that both relate more to 'experience' than to 'shopping'. 
Exemplar results from the semi-structured questionnaire interviews of 40 respondents are reproduced below. Respondents were asked: 'if the shopping centre were (for example) an animal, which one would you compare it with? Please explain why?' The most popular choices, with typical explanations were:

Animal

Metropolitan

Elephant 35\%

Big, boring, not colourful

Woodlands

Peacock $80 \%$

Colourful, elegant, attractive

Stone

Metropolitan

Amethyst 30\%

Diamond 55\%

Reasonably nice, not glamorous/exciting

Woodlands

Hobby

Metropolitan

Gardening 50\%

Hard work but end result enjoyable

Woodlands

Horse racing $35 \%$

Appeals to working and upper classes

Fruit

Metropolitan

Banana 35\%

Affordable but unattractive

Woodlands

Mango 45\%

Unique, expensive taste

Car

Metropolitan [Name omitted] 55\% Working class, low profile image

Woodlands

BMW 70\%

Class, status style

Newspaper

Metropolitan

Mirror 65\%

Working or middle class, mediocre

Woodlands

Guardian $40 \%$

High standard, quality.

Shoppers clearly considered that the 'personality' of a shopping centre is reflected in the type of person who uses the centre. Of course, few shoppers using the Metropolitan Centre would describe themselves in the terms used by the focus groups. Indeed, shoppers at the Metropolitan Centre usually stressed that they, personally, were not the typical Metropolitan Centre shopper - they were only there to buy a particular item or visit a specific shop.

\section{Quantitative}

The values for the 'Attractiveness index' brand image on the 1 to 100 scale were:

Blue Rose Centre

White Water Centre
69.4

64.9 
The Woodlands

Jubilee Centre

Metropolitan Centre

Greenleys
60.9

55.5

52.4

51.3

The Woodlands - the centre with the 'strong and vibrant' personality - scored significantly higher than the 'dull and boring' Metropolitan Centre (at $p=0.05,2$ sample $t$-test, Morris, 1989).

As mentioned in the 'Methodology and procedures' section above, for convenience in comparison and prediction, the authors' brand image measure has been re-scaled to use an equivalent numerical scale to the 'Mintel' score. The new attractiveness brand image scale was named the 'Brunel Index'. This Brunel Index, derived from the survey has been evaluated in terms of the degree of association with shopping centre sales turnover, rental income, and hinterland (catchment area) boundaries.

Firstly, Figure 1 illustrates the relationship between the measured brand image and the estimated sales turnover for the six centres. The sales value scale has been changed by an arithmetical factor in order to disguise commercially sensitive data. The sales turnover values are necessarily estimates and are of doubtful accuracy. These sales turnover estimates have been derived from the questionnaire responses for respondents' spend in the average month multiplied by visits per month data supplied by the centre managements. The respondents' recollections of spend and the managements' figures for visit rates must be of suspect accuracy. The estimates, though, were made before the Brunel Index was designed - and were not used in the development of the index.

Rental income, though, is in some cases is known with greater reliability than sales turnover. Figure 2 illustrates the relationship of attractiveness with rental income. The sources of the rental income figures are unreferenced as including them would compromise the centre owners' desires for anonymity, but the figures are taken from audited documents in the public domain. Three of the graph points in Figure 2 are measured Brunel Index values (rescaled to the same scale as the 'Mintel' scores. The other points are Mintel scores for centres not part of this empirical study. It is striking to note that the model based on the centres surveyed 'fits' predictions of rental values for 
centres not used in developing the model with a coefficient of determination of 0.98 (equivalent to the $\mathrm{R}^{2}$ measure - Hoel and Jesson, 1982).

Predicting the distance that a shopping centre's catchment extends and comparing the predictions with survey results can further validate the Brunel Index brand image measure. Spatial interaction ('gravitational') models of catchment area are based on the supposition that patronage of a town or shopping centre decreases with increasing distance from the centre - specifically that the patronage level divided by the distance raised to some power is a constant. The power to which the distance must be raised is defined as the 'distance exponent' - a parameter that is notoriously difficult to predict.

Dennis and colleagues (2000a) explored the relationship between the attractiveness of shopping centres and the distance exponent (with patronage based on visit rate per 1000 residents). Here, we have used the Dennis model to compare predicted with observed values for two further centres. We have not used data gathered in our own questionnaire surveys as to do so would involve an element of recursiveness (our distance decay data were used in generating our model). Published data are sparse but we have used values derived from Howard (1993) and Victoria Centre ( 1987) respectively for comparison with our predicted values:

$\begin{array}{lcc} & \text { Predicted } & \frac{\text { Actual }}{-1.48} \\ \text { Meadowhall } & -1.66 & -0.97\end{array}$

Predicted distance exponents have also been used to predict hinterland (catchment area) boundaries. Unfortunately, catchment area details for Nottingham were not available. Instead, we have substituted Northampton derived, using data derived from Martin (1982). The Meadowhall data were again derived from Howard (1993). The measures of 'fit' of the predictions to the survey were:
Northampton
0.82
Meadowhall
0.77

(Coefficients of determination of radii in the directions of towns - equivalent to the $\mathrm{R}^{2}$ measure - Hoel and Jesson, 1982). 


\section{Implications and Conclusions}

Branding can be quantified by, for example, Aaker's (1991) procedure of multiplying 'Importance' by 'Rating' and by Butterfield and Haigh's (1998) assignment of weights to brand attributes (the Interbrand or Brand Finance method). The authors have (in effect) combined these two approaches and modelled attribute weights from the association between shopping centre attractiveness attributes and shopper spending behaviour, developing the Brunel Index for brand image.

As far as can be determined from the data available, the Brunel Index for brand image does have meaning and utility. In the qualitative comparison of two centres, the centre attracting the more favourable descriptions was significantly higher rated than the other centre. The attractiveness measure has been successfully correlated with the estimated sales turnover of shopping centres. Furthermore, models have been developed and applied to data not used in generating the models to predict rental incomes, distance exponents and hinterland boundaries for shopping and town centres.

At the start of this paper it was contended that 'Active management' and 'Pro-active marketing' are central to UK shopping centre success. The term 'branding' has been little used by academics or practitioners with respect to shopping centres. Nevertheless, this work has demonstrated that shopping centres can be described in brand personality terms. The Brunel Index for brand image has been demonstrated to measure and predict success for the exemplar samples of shopping centres. There is a direct parallel here with the studies of consumer products that have demonstrated that the most highly branded products are the most profitable ones (e.g. Buzzell and Gale, 1987). Therefore, we contend that active brand management of shopping centres should pay rewards in terms of customer numbers, sales turnover and rental income - as with other consumer products, so with shopping centres.

What form should active brand management take? Firstly, some pointers can be deduced from the table of attribute weights in Appendix 2. These are the attributes that carry most weight in the brand image model, ranked in order of their association with shoppers' 
relative spend. Of these main components of brand image, only one, (quality of the stores) directly concerns shops. Three relate to infrastructure and six appear to us to be 'service' or 'experience'. Monitoring and managing the service and experience elements is crucial to shopping centre brand image and success. Other attributes, such as size of the centre and range of stores are also important, but tend to be relatively similar between competing centres, and therefore do not appear in our list of 'critical' attributes - i.e. those having most weight in shoppers choices of centres.

Secondly, brands can be built by planning and controlling aspects such as those listed by Jobber (referred to in the 'Introduction and conceptual framework' section of this paper above).

\section{Being First}

In the UK context, there may be a competitive advantage to be gained, not from being first as a shopping centre, but from being the first shopping centre (group?) to be truly branded, building the brand (for example) in line with these guidelines.

\section{Quality}

In shopping centres as in other consumer brands, better quality of the core product is associated with higher market share and profitability. Failure to get this right is a major reason for brand failure. Appendix 2 provides a checklist; for example, it is easy to observe less successful centres failing on basics such as cleanliness and toilets.

\section{Positioning, repositioning and long-term perspective}

Positioning in the marketplace involves the creation of a clear differential advantage in the minds of the shoppers, which can be achieved for example through brand name, image, service and design. As Jobber pointed out, Swatch successfully augmented a basic product - a watch - to create appeal for their target market by using colour and design. A look at the dark colour scheme of the poorly branded Metropolitan Centre, compared with the light and airy atmosphere of The Woodlands demonstrates the relevance for shopping centres. Market research should be carried out to track changes in shopper requirements 
and reposition accordingly. Jobber quotes Sir Adrian Cadbury (then chair of Cadbury Schweppes):

'For brands to endure they have to be maintained properly and imaginatively. Brands ... like other forms of property, ... need to be kept in good repair [and] renewed from time to time.'

The Metro Centre at Gateshead, UK, for example, was the largest and most modern shopping centre in Europe when opened in the mid 1980s. By the time of the take-over by CSC in the mid 1990s, though, there was considerable scope for repositioning and a revamp of the image by CSC's 'active management'.

\section{Internal marketing}

Internal marketing is a building block in the process of satisfying external customers. Internal 'customer service' and 'marketing research' in the form of, for example, anonymous staff surveys, suggestions and complaints schemes can contribute to the differences in success of companies whose external mixes appear evenly matched. CSC, for example, have demonstrated a proactive approach to motivation and training - perhaps a contributory factor to the rapid improvement of results at the Metro Centre under CSC ownership. In the context of shopping centres, though, there is a further dimension to internal marketing - there are potential benefits from information sharing between centre management and retailers (Dennis et al., 2000c).

\section{Credibility and well-blended communications}

It is not enough just to offer a quality product; consumers must be aware of the benefits and values and have confidence in the brand. Marketers use stimuli to communicate brand personality and reinforce favourable attitudes; the Esso tiger, for example, symbolising grace and power. Our qualitative work has identified some of the cues that could be used in advertising to associate a shopping centre with a positive personality image - peacock, diamond, horse racing, BMW and so on.

In conclusion, this exploratory study has demonstrated that techniques of brand image measurement can be used for shopping centres. Those with the better brand images tend to have larger catchment areas, sales, and rental incomes. It would be natural to expect that, 
that, for a shopping centre owner, achieving higher rental incomes should lead in turn to increased profits and shareholder returns - therefore in turn increasing the values of our pension funds. The authors have no evidence as to whether or not those centres scoring higher on the brand image measures have achieved their success by active brand management. Of the brand-building ideas that we have discussed, only 'quality' could be considered to have been measured directly in this study. Nevertheless, it should be axiomatic that applying brand-building techniques would enhance brand image, and we would contend that the range of brand-management tools should be managed together to achieve congruence in the brand image. Preliminary ideas have been presented and further work is recommended to develop these. Despite the concept of branding being little used by shopping centres, we contend that active brand management should pay rewards in terms of customer numbers, sales turnover and rental income. The models outlined here can measure and predict the effects of changes to individual attributes on these dependent variables.

For the future, confirmatory studies of more shopping centres and more respondents, recorded over a wider range of shopping times, are recommended. 


\section{Appendix 1}

\section{Focus group constructs}

The focus group records were coded and interpreted by the authors. The constructs below are considered to summarise the essence of what respondents considered good or bad about the centres or illustrative of their 'personalities'.

\section{Metropolitan Centre: 'Good' constructs}

\begin{tabular}{|l|l|}
\hline Access by all types of transport & $\mathrm{B}, \mathrm{D}^{1}$ \\
\hline Car park & $\mathrm{D}, \mathrm{K}^{2}$ \\
\hline Functional shopping, convenience, good for quick shop & $\mathrm{C}$ \\
\hline Good for specific item & $\mathrm{F}$ \\
\hline Value for money & $\mathrm{K}^{2}$ \\
\hline Shops like computer games and music attractive to teenagers & $\mathrm{S}$ \\
\hline
\end{tabular}

1 The initial letters are code identifiers for the focus groups

2 Focus group $\mathrm{K}$ was the final, more representative, one.

Metropolitan Centre: 'Bad' constructs

\begin{tabular}{|l|l|}
\hline Security & $\mathrm{B}, \mathrm{S}$ \\
\hline Teenagers & $\mathrm{B}, \mathrm{S}$ \\
\hline Lack of class shops & $\mathrm{D}$ \\
\hline Centre too small & $\mathrm{K}^{2}$ \\
\hline Limited breadth of offering & $\mathrm{C}$ \\
\hline Crowded & $\mathrm{K}^{2}$ \\
\hline Limited opening hours & $\mathrm{K}^{2}$ \\
\hline Not enough toilets & $\mathrm{K}^{2}$ \\
\hline Dark & $\mathrm{F}$ \\
\hline Poor ambience, atmosphere & $\mathrm{C}$ \\
\hline Poor surrounding facilities & $\mathrm{C}$ \\
\hline $\begin{array}{l}\text { No attractions or personality. Used to be good for families, now } \\
\text { 'Poundsaver' }\end{array}$ & $\mathrm{S}$ \\
\hline
\end{tabular}

Metropolitan Centre: 'Personality'

\begin{tabular}{|l|l|l|}
\hline Animal & Cat or dog (wide appeal/not exciting, just OK) & D, K \\
& Hedgehog, mole, rat & S \\
& Porcupine & B, C \\
\hline Car & [Names omitted to avoid defamation] (Does not work) & $\mathrm{S}$ \\
\hline Clothing & Crumpled suit & $\mathrm{B}$ \\
& Shell suit & $\mathrm{C}$ \\
\hline Person & Dull, boring, old fashioned & $\mathrm{K}^{2}$ \\
& Lower working class or elderly & $\mathrm{K}^{2}$ \\
& Young, untidy male & $\mathrm{S}$ \\
\hline
\end{tabular}

The Woodlands: 'Good' constructs

\begin{tabular}{|l|l|}
\hline Wide range of good quality shops for all the family & B \\
\hline More variety, better quality bigger shops & F \\
\hline Good security & B \\
\hline
\end{tabular}




\begin{tabular}{|l|l|}
\hline Good décor and layout & F \\
\hline Crèche & F \\
\hline
\end{tabular}

The Woodlands: 'Bad' constructs

\begin{tabular}{|l|l|}
\hline Not enough car parking & $\mathrm{B}$ \\
\hline Expensive parking & $\mathrm{K}^{2}$ \\
\hline Town centre layout confusing & $\mathrm{B}$ \\
\hline High prices & $\mathrm{K}^{2}$ \\
\hline
\end{tabular}

The Woodlands: 'Personality'

\begin{tabular}{|l|l|l|}
\hline Animal & $\begin{array}{l}\text { Tiger, lion, peacock (strong, vibrant, big, colourful) } \\
\text { Lion }\end{array}$ & $\begin{array}{l}\mathrm{K}^{2} \\
\mathrm{C}\end{array}$ \\
\hline Car & Jaguar (flash, nice, clean) & $\mathrm{S}$ \\
\hline Clothing & Designer suit & $\mathrm{B}, \mathrm{C}$ \\
\hline Person & Prestige, trendy, good taste, enjoys leisure, very smart & $\mathrm{K}^{2}$ \\
\hline
\end{tabular}

\section{Appendix 2}

The 'top ten' attribute weights from the quantitative survey are listed below. These were the attributes most associated with relative spend at the six shopping centres (all were significantly so at $\mathrm{p}=0.05$ ). These are not necessarily the attributes that the respondents considered most 'important' as the 'weight' also takes into account the degree and strength of the association of the respondents' rating of the attribute with relative spend. Hence 'weight' is intended to model the weight that the attribute carries in shopper spending decisions. In this table, less significant attributes have been omitted, but the numerical values are scaled such that if all attributes are included, the weights total 100.

$\begin{array}{llc}\text { Rank } & & \text { Attribute weight } \\ 1 & \text { General layout } & 11.4 \\ 2 & \text { Access by car (roads) } & 7.8 \\ 3 & \text { Nice place to spend time } & 6.7 \\ 4 & \text { Cleanliness } & 6.0 \\ 5 & \text { Covered shopping } & 4.5 \\ 6 & \text { Quality of stores } & 3.9 \\ 7 & \text { Shoppers nice people } & 3.9 \\ 8 & \text { Availability of toilets } & 3.9 \\ 9 & \text { Friendly atmosphere } & 3.8 \\ 10 & \text { Helpfulness of staff } & 3.1 .\end{array}$

\section{Acknowledgements}

The authors thank Professor Peter McGoldrick of UMIST for posing many searching questions on early versions of the results, Heli Marjanen of Turku School of Business Administration for providing much extra useful information and Meera Doolub and Chris Jackson for assistance with data gathering. 


\section{References}

Aaker D A (1991) Managing Brand Equity, New York, Free Press.

Aaker J L (1997) 'Dimensions of brand personality', Journal of Marketing Research, 24 (August): 347-356.

Akehurst G and Alexander N (1995) The Internationalisation of Retailing, London, Frank Cass.

Alt M and Griggs S (1988) 'Can a brand be cheeky?' 31st Annual Conference, London, Market Research Society: 99-127.

Association of Town Centre Management (1994) The Effectiveness of Town Centre Management - Research Study, Association of Town Centre Management, London.

Birkin M (1994) 'Assessing brand value', in Brand Power, Stebart P (ed.), Basingstoke, Macmillan.

Brand Finance (1999) The Brand Finance Report, Kingston upon Thames, Brand Finance plc.

Burns D J and Warren H B (1995) 'Need for uniqueness: shopping mall preference and choice activity', International Journal of Retail and Distribution Management, 23 (12).

Butterfield L and Haigh D (1998) Understanding the Financial Value of Brands, London, Institute of Practitioners in Advertising.

Buzzell R and Gale B (1987) The PIMS Principles, London, Collier Macmillan.

CSC (1996) 1996 Annual Report and Accounts, London, Capital Shopping Centres PLC.

Carlson H J (1991) 'The role of the shopping centre in US retailing', International Journal of Retail and Distribution Management, 19 (6): 91.

Cavanaugh T (1996) 'Mall crawl palls' American Demographics, (Sept).

Christaller W (1933) Central Places in Southern Germany (translated by Baskin C, 1966), Englewood Cliffs, NJ, Prentice Hall.

Cooke J (1993) 'The shopping challenge - centres without a future', in Henry Stewart Conference Studies (Ed.), Latest Developments in the Ongoing Marketing and Promotion of Shopping Centres, London, 29 September: 1-9.

Davies G (1998) 'Retail Brands and the theft of identity', International Journal of Retail and Distribution Management, 26 (4-5): 140-146.

Davies R, Howard E and Reynolds J, (1993) The Shopping Centre Industry 1993: Thirty Years of Growth, Oxford, Oxford Institute of Retail Management/British Council for Shopping Centres.

De Chernatony L and McDonald M H B (1998) Creating Powerful Brands in Consumer, Service and Industrial Markets, Oxford, Butterworth-Heinemann.

Dennis C E, Marsland D and Cockett W A (1999) 'Why do people shop where they do?' Recent Advances in Retailing and Services Science, 6th International Conference, Eindhoven, The Netherlands, The European Institute of Retailing and Services Studies

Dennis C E, Marsland D and Cockett W A (2000a), 'Objects of desire: attraction and distance in shopping centre choice', International Journal of New Product Development and Innovation Management, (2) 2: 43-60.

Dennis C E, Marsland D and Cockett W A (2000b) 'Central place theory revisited: the use of attractiveness measures in predicting shopping centre catchment area boundaries' Recent Advances in Retailing and Services Science, 7th International Conference, Eindhoven, The Netherlands, The European Institute of Retailing and Services Studies. 
Dennis C E, Marsland D and Cockett W A (2000c) 'Beyond the loyalty card? Possibilities for data mining for shopping centres - a customer knowledge management framework' Retailing 2000: Launching the New Millennium, $6^{\text {th }}$ Triennial AMS/ACRA Retailing Conference, Columbus, Ohio, Hofstra University/Academy of Marketing Science/American Collegiate Retailing Association.

Doyle P (1989) 'Building Successful Brand: the Strategic Options', Journal of Marketing Management, 5 (1): 77-95.

Fishbein M (1963) 'An investigation of the relationships between beliefs about an object and the attitude towards the object', Human Relations 16: 223-240.

Fransella F and Bannister P (1977) A Manual for Repertory Grid Technique, London, Academic Press.

Gibson B (1999) 'Beyond shopping centres - e-commerce' British Council of Shopping Centres Conference.

Guy C M (1994) The Retail Development Process: location, property and planning, London, Routledge.

Hackett P M W and Foxall G R (1994) 'A factor analytic study of consumers' location specific values: a traditional high street and a modern shopping mall', Journal of Marketing Management 10: 163-178.

Hallsworth A G (1988a) 'Repertory grid methodology and the analysis of group perceptions in retailing', International Journal of Retailing, 3 (4): 43-54.

Hallsworth A G (1988b) The Human Impact of Hypermarkets and Superstores, Aldershot, Avebury.

Hankinson G and Cowking P (1993) Branding in Action Maidenhead, McGraw-Hill.

Hoel P G and Jessen R J (1982) Basic Statistics for Business and Economics, New York, Wiley.

Howard E (1992) 'Evaluating the success of retail out of town shopping centres', The International Review of Retail, Distribution and Consumer Research, 2 (1) 59-80.

Howard E (1993) 'Assessing the impact of shopping centre development: the Meadowhall case, Journal of Property Research, 10: 97-119.

Howard E (1995) Partnerships in Shopping Centres, Oxford, OXIRM

Howard E (1997) 'The management of shopping centres: conflict or collaboration?', The International Review of Retail, Distribution and Consumer Research, 7 (3): 263-286.

Howell R D and Rogers J D (1980) 'Research into shopping mall choice behaviour', in Monroe K B (ed., 1980) Advances in Consumer Research, Ann Arbor, Association for Consumer Research.

Huff D L (1964) 'Defining and estimating a trade area', Journal of Marketing, 28 (July): 34-38.

Jary M and Wileman A (1998) 'Managing retail brands', in Hart S and Murphy J (eds., 1998), Brands: the New Wealth Creators, Basingstoke, Macmillan Business.

Jobber D (1995) Principles and Practice of Marketing, London, McGraw-Hill.

Jobber D (2001) Principles and Practice of Marketing, $3^{\text {rd }}$ edition, London, McGrawHill.

Kelly G A (1955) The Psychology of Personal Constructs, Vols. 1-2, New York, Norton. King S (1991) 'Brand Building in the 1990s, Journal of Marketing Management, 7 (1): 314.

Kirkup M H and Rafiq M (1999) 'Marketing shopping centres: challenges in the UK context', Journal of Marketing Practice, 5 (5): 119-133.

McGoldrick P J (1990) Retail Marketing, Maidenhead, McGraw Hill. 
McGoldrick P J and Thompson M G (1992a) 'The role of image in the attraction of the out of town Centre', The International Review of Retail, Distribution and Consumer Research 2 (1): 81-98.

McGoldrick P J and Thompson M G (1992b) Regional Shopping Centres: Out-of-Town versus In-Town, Aldershot, Avebury.

Management Horizons (1995) Index of Shopping Venues, London, Management Horizons.

Marjanen H (1993) Store Location Analysis and the Mystery of Consumer Spatial Behaviour: competition between downtown shopping areas and out-of-town shopping centres as a special case, Turku (Finland), Turku School of Economics and Business Administration.

Martin P G (1982) Shopping Centre Management, London, Spon.

Martineau P (1958) 'The personality of the retail store', Harvard Business Review, 36 (1): 47-55.

Medway D, Alexander A, Bennison D and Warnaby G (1999) 'Retailers' financial support for town centre management', International Journal of Retail and Distribution Management, 27 (6-7): 246.

Medway D, Warnaby G, Bennison D, and Alexander A (1999) 'Reasons for retailers' involvement in town centre management', International Journal of Retail and Distribution Management, 28 (8-9): 368-369.

Mintel (1997) Shopping Centres, London, Mintel.

Mitchell V-W and Kiral H R (1999) 'Risk positioning of UK multiple retailers', The International Review of Retail, Distribution and Consumer Research, 9 (1): 17-39.

Morris C (1989) Quantitative Approaches in Business Studies, London, Pitman.

Murphy J (1989) Brand Valuation: Establishing a True and Fair View, London, Business Books.

Murphy J (1998) 'What is branding', in Hart S and Murphy J (eds., 1998), Brands: the New Wealth Creators, Basingstoke, Macmillan Business.

Opacic S and Potter R B (1986) 'Grocery store cognitions of disadvantaged consumer groups: a Reading case study', Tijdschrift voor Econ. en Soc. Geografie, 77 (4): 288-298.

Oppewal H and Timmermans H (1999) 'Modelling consumer perception of public space in shopping centres', Environment and Behaviour, 31 (1): 45.

Osgood G E, Suci G J and Tannenbaum P M (1957) The Measurement of Meaning, Urbana, Illinois, University of Illinois.

OXIRM (1999) The Shopping Centre Industry: its Importance to the UK Economy, Oxford, Oxford Institute of Retail Management/MCB.

Phipps R and Simmons C (1996) Understanding Customers, Oxford, ButterworthHeinemann.

PreFontaine M (1999) 'Beyond shopping centres - e-commerce' British Council of Shopping Centres Conference.

Randall G (1997) Branding, London, Kogan Page.

Redstone L G (1973) New Dimensions in Shopping Centres and Stores, New York, McGraw Hill: xvii.

Richards I, Foster D and Morgan R (1998) 'Brand knowledge management: growing brand equity', Journal of Knowledge Management, 2 (1): 47-54.

RICS Foundation (2000) 20:20 Visions of the Future, Royal Institute of Chartered Surveyors 
SERPLAN (1987) Retail Monitoring Working Party. Regional shopping centres around London: background papers, London, SERPLAN.

Swinyard W R (1992) 'An opportunity based model of customer service', The International Review of Retail, Distribution and Consumer Research 2 (1): 1-12.

Timmermans H, Van Der Heijden R and Westerfield H (1982) 'Cognition of urban retailing structures: a Dutch case study', Tijdschrift voor Econ. en Soc. Geografie, 1:2-12. Victoria Centre ( 1987) Victoria Centre Information Pack, Capital shopping Centres.

Wakefield K L and Baker J, (1998) 'Excitement at the mall: determinants and effects on shopping response', Journal of Retailing, 74 (4): 515.

Warnaby G and Davies B J (1997) 'Commentary: cities as service factories? Using the Servuction system for marketing cities as shopping destinations, International Journal of Retail and Distribution Management, 25 (6-7): 204-210.

Warnaby G (1998) 'Marketing UK cities as shopping destinations: problems and prospects', Journal of Retailing and Consumer Services, 5 (1): 55-58.

Warnaby G and Medway D (2000) 'Competitive Responses by Town Centres to OffCentre Retail Developments', The Planning and Management of Retail Locations, Annual Manchester Conference for Contemporary Issues in Retail Marketing', Manchester Metropolitan University. 


$$
\begin{gathered}
y=0.0014 x^{2}+1.1134 x \\
R^{2}=0.9867
\end{gathered}
$$

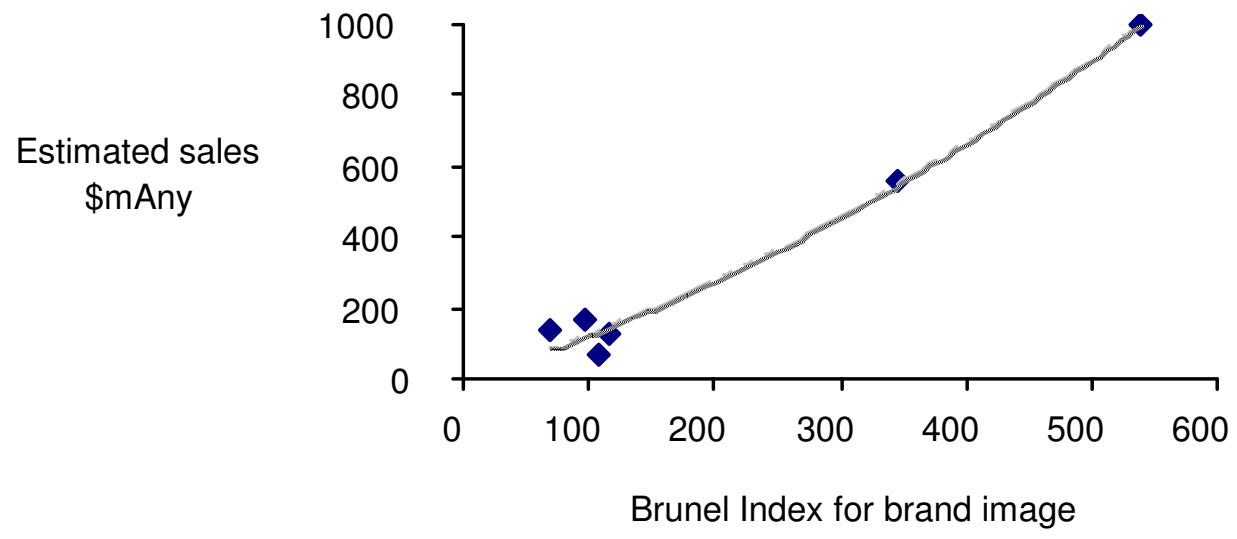

Figure 1 Estimated sales of shopping centres

vs. the Brunel index for brand image polynomial plot forced through the origin 


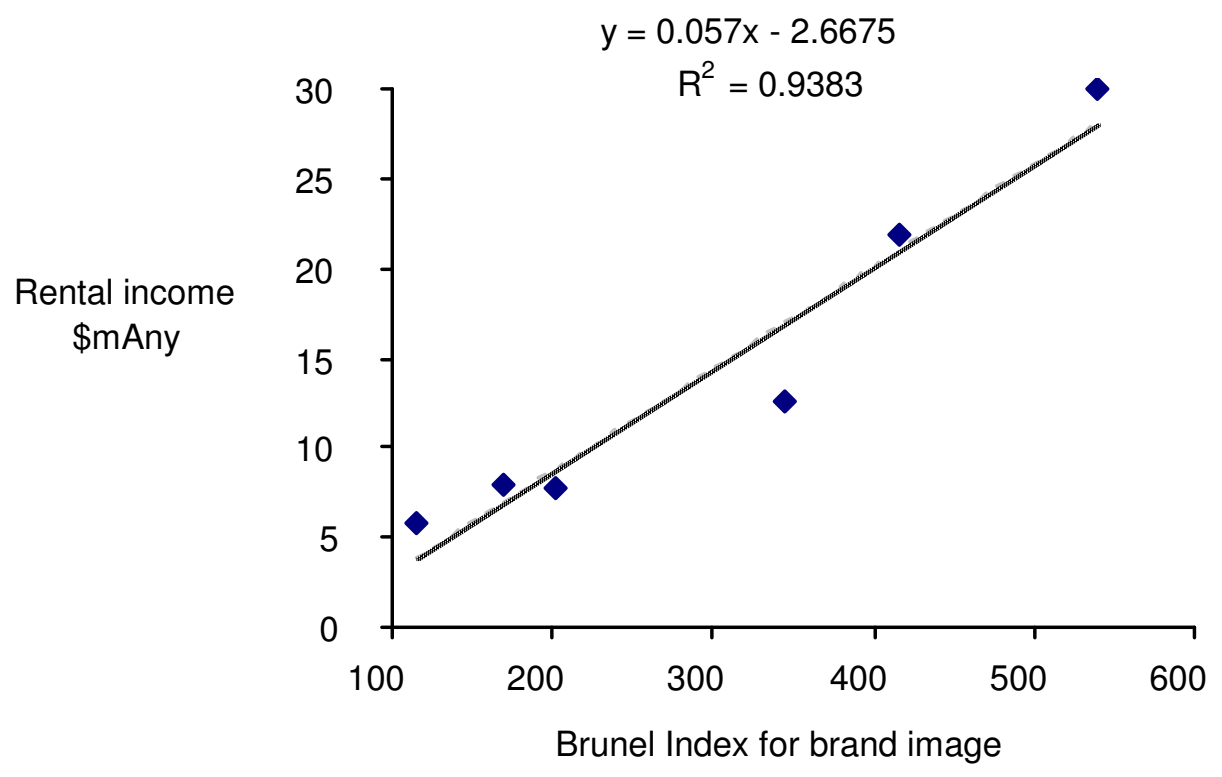

Figure 2 Rental income of shopping centres vs. the Brunel Index for brand image where known, otherwise

'Mintel' score - corrected for towns 